\title{
Cluster and Principal Components Analyses on the Contents of (Total and Sorbed) Trace Metals in Fresh Marine Sediments from the Southwest of the Gulf of Mexico
}

\author{
Análisis de componentes principales y clusters de metales trazas \\ (totales y sorbidos) en sedimentos marinos recientes \\ del Suroeste del Golfo de México
}

\author{
De Lorenz-Santos Fernando Jesús \\ Facultad de Ingeniería \\ División de Ingeniería Civil y Geomática \\ Universidad Nacional Autónoma de México \\ E-mail:fersin562000@yahoo.com.mx
}

\author{
Vázquez Felipe ${ }^{\dagger}$ \\ Laboratorio de Fisicoquímica Marina \\ Instituto de Ciencias del Mar y Limnología \\ Universidad Nacional Autónoma de México
}

\author{
Fernández-Villagómez Georgina \\ Facultad de Ingeniería \\ División de Ingeniería Civil y Geomática \\ Universidad Nacional Autónoma de México \\ E-mail:gfv19@hotmail.com
}

\author{
Cervini-Silva Javiera \\ Departamento de Procesos y Tecnología \\ División de Ciencias Naturales e Ingeniería \\ Universidad Autónoma Metropolitana Unidad Cuajimalpa \\ E-mail:jcervini@correo.cua.unam.mx
}

Information on the article: received: April 2012, reevaluated: August 2012, accepted: December 2012

\begin{abstract}
The amounts of total and sorbed $\mathrm{Al}, \mathrm{Ba}, \mathrm{Cr}, \mathrm{Fe}, \mathrm{Mn}, \mathrm{Ni}$, and $\mathrm{V}$ present in three sediment cores from the South of the Gulf of Mexico (N1, N2, and N3) were determined. Of the three samples studied herein (N1. N2, and N3), one of them (N2) is associated to a natural "chapopotera". ICP/MS analyses show that total concentrations of $\mathrm{Al}, \mathrm{Fe}, \mathrm{Mn}, \mathrm{Ba}, \mathrm{Cr}, \mathrm{Ni}, \mathrm{Pb}$, and $\mathrm{V}$ for $\mathrm{N} 1$ and $\mathrm{N} 3$ were found to be ca. 4.2, 2.3, 206.5, 165, 91, 72, 14 and $97 \mathrm{mg} \mathrm{kg}^{-1}$, and ca. $5.2\left(\mathrm{Al}_{2} \mathrm{O}_{3}\right)$, $4,401.50,269,89,62,18$, and $118 \mathrm{mg} \mathrm{kg}^{-1}$ for N2. As evidenced by the correlation matrices, there is a positive association among metals distribution, except for the case of Mn, regardless of the sediment core. Nevertheless, Cluster and Principal Components Analyses denote variability in metal-spatial distribution, signature variability in the composition of the water column. Magnitude values for the enrichment factor (EF) relative to background values found in the Southern Gulf of Mexico (bulk seawater) for $\mathrm{Al}, \mathrm{Fe}, \mathrm{Mn}, \mathrm{Ba}, \mathrm{Cr}, \mathrm{Ni}, \mathrm{Pb}$, and $\mathrm{V}$ were estimated. The outcome of this work show distinctive EF values, ranging from moderate to high EF values, regardless of the core source.
\end{abstract}

\section{Keywords:}

- trace metals partitioning

- enrichment factor

- "chapopotera" 


\section{Resumen}

Se determinaron las cantidades total y adsorbidas de $\mathrm{Al}, \mathrm{Ba}, \mathrm{Cr}, \mathrm{Fe}, \mathrm{Mn}, \mathrm{Ni}, \mathrm{y} \mathrm{V}$ presentes en tres núcleos de sedimentos del Sur del Golfo de México (N1, N2 y N3). De las tres muestras estudiadas en el presente documento, una de ellas (N2) se asocia a las chapopoteras naturales. El análisis en ICP/MS demuestra que las concentraciones totales de $\mathrm{Al}, \mathrm{Fe}, \mathrm{Mn}, \mathrm{Ba}, \mathrm{Cr}, \mathrm{Pb}$ y V para el N1 y N3 son 4.2,2.3, 206.5, 165, 91, 72, 147 y $97 \mathrm{mg} \mathrm{kg}^{-1}$, y para N2 son $5.2\left(\mathrm{Al}_{2} \mathrm{O}_{3}\right), 4$, 401.50, 269, $89,62,18$, and $118 \mathrm{mg} \mathrm{kg}^{-1}$. Como se evidencia por las matrices de correlación, existe una relación positiva entre la distribución de los metales excepto para el $\mathrm{Mn}$, independientemente del núcleo de sedimentos. Sin embargo, el Cluster y análisis de componentes principales denotan la variabilidad de la distribución espacial del Mn, la cual se confirma en la columna de agua. También se calcularon valores de magnitud para el factor de enriquecimiento (EF) de $\mathrm{Al}, \mathrm{Fe}, \mathrm{Mn}, \mathrm{Ba}, \mathrm{Cr}, \mathrm{Ni}, \mathrm{Pb}$, y $V$, relativos a los valores del fondo que se encuentran en el sur del Golfo de México (mar grueso). Finalmente, el resultado de este trabajo muestra valores y comportamiento distintivos del EF, que van de moderados a altos, independientes de su fuente principal.

\section{Descriptores:}

- partición de metales traza

- factor de enriquecimiento

- "chapopoteras"

\section{Introduction}

Metals are pivotal to biogeochemical processes, thereby the importance of understanding their partitioning mechanism(s) in marine sediments; particularly so in either mineral surfaces or biological matrices. In the former case, metal sorption in marine sediments will vary depending on $\mathrm{pH}$, redox potential, and the composition of suspended solids (Kitano and Fujiyoshi, 1980; Hakansson et al., 1989; Calmano et al., 1993; Wiechula et al., 2000). In the latter case, metals will interact with organic matter (humic acid), $\left(\mathrm{HS}^{-}, \mathrm{S}^{=}\right)$, and react with other metals, prior to entering to the trophic chain (Ford and Ryan, 1995; Bosecker, 1997; Schippers and Sand, 1999; Gutjahr et al., 2007; Sparrevik et al., 2009; Scholz et al., 2009). Three main rivers, namely, Grijalva, San Pedro, González, Tonalá, and Coatzacoalcos drain to the South of the Gulf of Mexico. These rivers carry high contents of suspended solids. Such high turbidity has been attributed in part to changes in the land use and deforestation (Vázquez et al., 2006; Vela, 2005). In particular, recent reports provide evidence to show water inflows from coastal rivers and lagoons containing suspended solids concentrations as high as ca. 10439 ton $\mathrm{d}^{-1}$ (PEP-UNAM, 2008; Scholz et al., 2009), with chemical components found in the deep zone, $\geq 3,000 \mathrm{~m}$. The presence of high amounts of suspended material has been explained by the inflows of the Coatzacoalcos and Grijalba-Usumacinta rivers in light that marine currents are responsible for distributing particulated coastal supplies into the deep zone (Vazquez and Alex- ander, 2008). Other anthropogenic-borne sources of particulated material prevailing in this geographical region include the presence of the oil industry and imminent natural oil spills commonly referred as "chapopoteras", marine-transit discharges, or atmospheric precipitation of $\mathrm{Pb}, \mathrm{Ni}, \mathrm{Ba}, \mathrm{V}, \mathrm{SO}_{x}$ and $\mathrm{NO}_{x}$ particles (Prospero, 1999; Prospero et al., 2004). All these input sources ensure the continuous accumulation of metals at the sediment-water pore interface. The purpose of this work was to study the spatial distribution of $\mathrm{Al}, \mathrm{Ba}$, $\mathrm{Cr}, \mathrm{Fe}, \mathrm{Mn}, \mathrm{Ni}, \mathrm{Pb}$ and $\mathrm{V}$, in three distinct sediment environments in from the South of the Gulf of Mexico. The study was conducted to better understand metals partitioning as characterized by Cluster and Principal Component Analyses based on Enrichment Factor (EF) determinations.

\section{Material and methods}

Three sediment cores were collected on board of the B/O (Oceanographic Vessel) Justo Sierra which belongs to the Universidad Nacional Autonoma de Mexico (UNAM). The collection sites for the sediment cores were located at the forefront of the Coatzacoalcos and Grijalva-Usumacinta. The site was affected by a natural oil spill (Figure 1).

The cores (N1, N2, and N3) were collected in $0.01 \mathrm{~m}^{3}$ boxes. Each core was $12 \mathrm{~cm}$ in diameter. The cores thickness varied from 12 to $31 \mathrm{~cm}$. The cores were collected using hydraulic PVC tubes. The tubes were washed with an acid solution and water Type III (mil- 


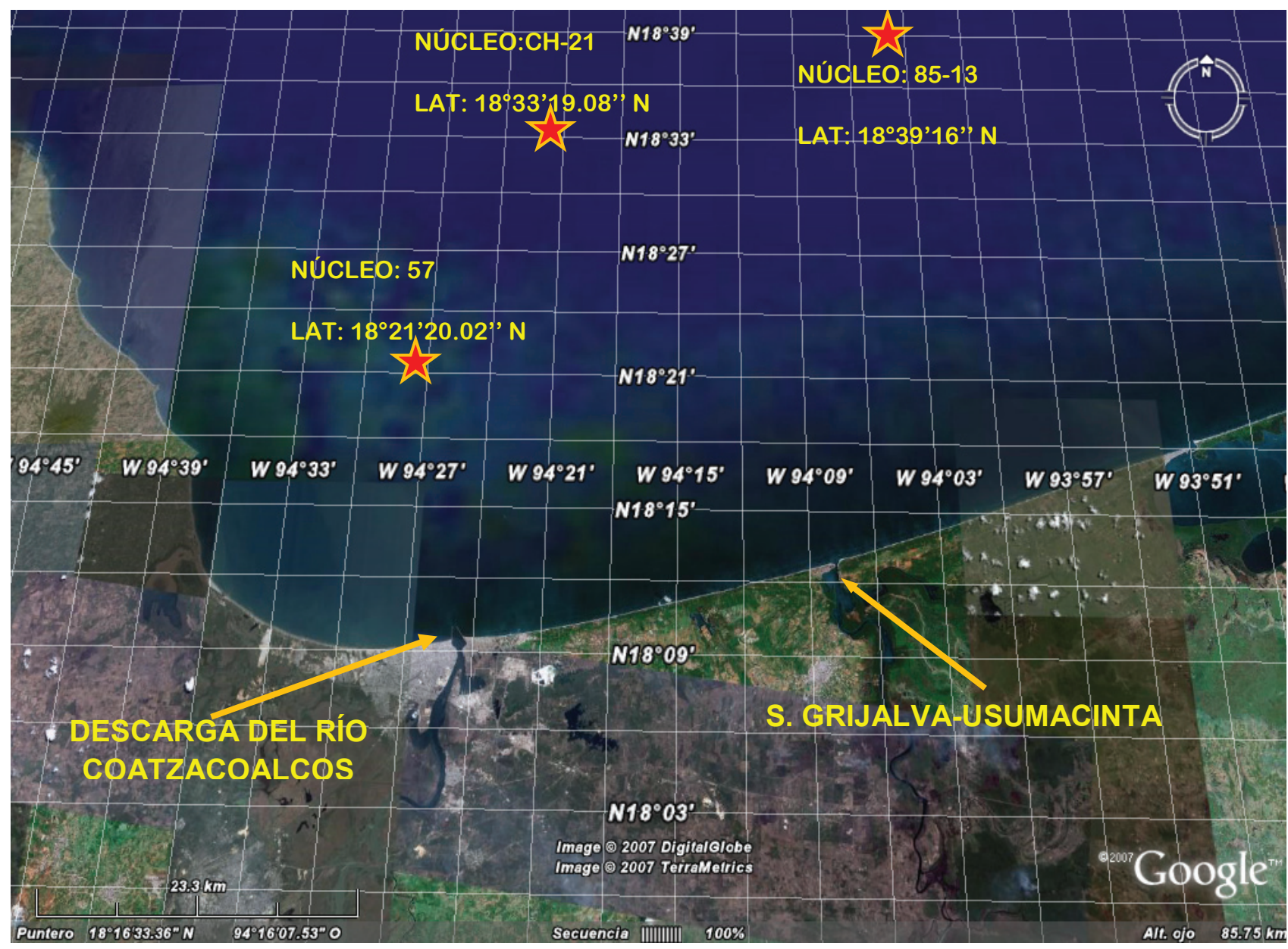

Figure 1. Location of sampling points in the Southern Gulf of Mexico (S7. Supplementary Information Section)

lipore, Milli-Q) prior to use. The sediment cores were stored in plastic bags right after collection. Plastic bags were opened right before use to prevent oxygen diffusion and a subsequent plausible metal-oxidation. In all samples, the supernatant water from the core top was removed. The cores were then sealed and cap-closed using Teflon cylinder(s). All cores collected were kept at $4^{\circ} \mathrm{C}$ prior to analyses (Figure 1 ).

The sediment samples were obtained by sectioning the cores at $0.5-\mathrm{cm}$ regular intervals for N1 and N2, and 1.0-cm regular intervals for N3. Twenty six samples for N1, 64 for N2, and 30 for N3 were obtained. The depths selected for this study were 2100 (N2), 250 (N1), and 15 m (N3). Sections of dry sediment were homogenized with an agate mortar and stored in high-density plastic jars. For determining total-metals contents, dry-sediment samples were digested in a $1: 1 \mathrm{HCl}: \mathrm{HNO}_{3}$ mixture inside a CEM MARS 5 microwave, according to a method reported by Tessier et al. (1979); De Lorenz
(2004); Vázquez et al. (2004), and (2006); PEP-UNAM, (2008). Metal quantification was conducted using an ICP/MS and Atomic Absorbance equipped with an impact cell and an automatic sampler. All experiments were analyzed randomly and by duplicates. The analytical recoveries relative to standard solutions (Highpurity standards; Lot number 830702, Cat. Number CRM-MS-S) for total-metal determinations were $91.5 \%$ for $\mathrm{Al} ; 94.5 \%$ for $\mathrm{Ba} ; 98.4 \%$ for $\mathrm{Cr} ; 99.5 \%$ for $\mathrm{Fe}$; $95.4 \%$ for $\mathrm{Mn} ; 95 \%$ for $\mathrm{Ni}$; and $97.5 \%$ for $\mathrm{V}$. For sorbed metals determinations, the analytical recoveries corresponded to $\mathrm{ca} .96 \%$ for $\mathrm{Al} ; 93 \%$ for $\mathrm{Ba}$; $87 \%$ for $\mathrm{Cr}$; $98 \%$ for $\mathrm{Fe}$; $85 \%$ for $\mathrm{Mn} ; 91 \%$ for $\mathrm{Ni}$; and $95 \%$ for $\mathrm{V}$.

\section{Results and discussion}

Our results show atypical values for all metals studied. The magnitude values for the concentrations of total metals revealed a broad distribution for $\mathrm{Fe}_{\mathrm{T}}$ (total $\mathrm{Fe}$ ), 
$\mathrm{Mn}_{\mathrm{T}}, \mathrm{Ba}_{\mathrm{T}}$, and $\mathrm{Al}_{\mathrm{T}}$. Mean values obtained indicate a higher data dispersion for the 50 and $75 \%$ quartiles, along with a concomitant negative data slanting. A comparison of the degree of data dispersion for the contents of sorbed and total metals for N1 shows a greater magnitude value for the contents of sorbed metals. A comparison between data trends obtained for $\mathrm{N} 1$ and N2 shows a difference in the distribution of total metals perhaps because of its proximity with natural "chapopoteras" (Scholz et al., 2009). The concentrations of $\mathrm{Mn}_{\mathrm{T}}$, are higher in magnitude for N2. Also, the distribution of sorbed metals was also found to vary from N1 to N2. The distribution of the data for sorbed metals in N2 was found to present a greater dispersion. This is particularly the case for either sorbed $\mathrm{Ni}\left(\mathrm{Ni}_{\mathrm{a}}\right)$ or $\mathrm{V}\left(\mathrm{V}_{\mathrm{a}}\right)$, arguably due to the presence of "chapopoteras". Also, sorbed $\mathrm{Fe}\left(\mathrm{Fe}_{\mathrm{a}}\right), \mathrm{Mn}\left(\mathrm{Mn}_{\mathrm{a}}\right)$, and $\mathrm{Ba}\left(\mathrm{Ba}_{\mathrm{a}}\right)$ were found to present lower magnitude values in N1 compared to N2 (S1, Supplementary Information Section).

Overall data trends showed higher dispersion values for N1. Finally, the amounts of Fe, either in dissolved $\left(\mathrm{Fe}_{\mathrm{s}}\right)$ or sorbed $\left(\mathrm{Fe}_{\mathrm{a}}\right)$ form, were found to surpass in magnitude those registered for any other metal. This was found to be the case in either N1 and N2. Total $\mathrm{Ba}\left(\mathrm{Ba}_{\mathrm{T}}\right), \mathrm{Cr}\left(\mathrm{Cr}_{\mathrm{T}}\right), \mathrm{Pb}\left(\mathrm{Pb}_{\mathrm{T}}\right)$, and $\mathrm{Mn}\left(\mathrm{Mn}_{\mathrm{T}}\right)$ magnitude values were found to be similar in $\mathrm{N} 2$ and N3. By contrast, total $\mathrm{Fe}\left(\mathrm{Fe}_{\mathrm{T}}\right), \mathrm{Ni}\left(\mathrm{Ni}_{\mathrm{T}}\right)$, and $\mathrm{V}\left(\mathrm{V}_{\mathrm{T}}\right)$ magnitude values in $\mathrm{N} 3$ were found to be higher relative to those found for $\mathrm{N} 1$ or N2. Total $\mathrm{Fe}\left(\mathrm{Fe}_{\mathrm{T}}\right), \mathrm{Mn}$ $\left(\mathrm{Mn}_{\mathrm{T}}\right), \mathrm{Ba}\left(\mathrm{Ba}_{\mathrm{T}}\right)$, and $\mathrm{V}\left(\mathrm{V}_{\mathrm{T}}\right)$ mean \pm S.E. values indicated a greater data dispersion between the 50 and $75 \%$ quartiles, along with a concomitant negative slanting of the data (S2 and S3, Supplementary Information Section).

The partitioning behavior of metals in the environment depends on the enlargement on their intrinsic reactivity, as well as biogeochemical conditions. In particular for $\mathrm{Al}$, a conservative element, the environmental fate is constrained by diffusion and precipitation-dissolution reactions processes (Caschetto and Wollast, 1979; Carroll et al., 2002). For these reasons, various researchers have suggested the usage of $\mathrm{Al}$ as an indicator of anthropogenic activity (Rubio et al., 2000; Rubio et al., 1998; Covelli and Fontolan, 1997; Balls et al., 1997; Marcet et al., 1997; Ryan and Windom, 1988). Pertinent herein is the fact that $\mathrm{Al}$ is found in abundance in native clay minerals from the South of the Gulf of Mexico (Scholz et al., 2009; PEP-UNAM, 2008; Vázquez et al., 2000). The variability observed for the $\mathrm{Cr}$ distribution among sediment cores can be attributed in part to the presence of either organic matter (Salomons and Förstner, 1984), iron and man- ganese oxides (Williams et al., 1974; Vázquez et al., 2000, 2004 and 2006), or iron-calcareous residues (Jickells and Knap, 1984). In deep zones, Cr becomes immobilized when reacting with aqueous Fe (II) (Lan et al., 2006). Iron reacts to form insoluble sulfides (Hurtgen et al., 1990; Carol et al., 2002). Data showing high concentrations of soluble iron, however, is explained by the sorption-desorption processes coupled with metal complexation by bioorganic compounds. The variability observed for the amounts of soluble $\mathrm{Mn}$ is explained in part by the formation of manganese oxides or manganese organic-matter complexes. Given that the sampling sites are biologically active (Anschutz et al., 2005), we do not discard the notion that Mn (III) becomes the predominant species. The variability observed among the contents of Ni can be explained by the interaction(s) with sulphide species or organic matter (Ni-OM); bioturbation; desorption; migration of $\mathrm{Ni}$ from the deep zone to the surface; biotransformations; or the ionization of $\mathrm{NiCO}_{3}$ species at the core deep zone (Williamson and Wilcock, 1994). Variations in $\mathrm{Pb}$ accumulation observed in the core deep zones can be explained in part by the formation of insoluble $\mathrm{Pb}$ sulfides, $\mathrm{Pb}$-organic matter complexes (Huerta and Morse, 1992; Vázquez et al., 2004), or $\mathrm{PbCO}_{3}$. Nevertheless, the high amounts of source $\mathrm{Pb}$ observed throughout the core are an indication of undersaturation with respect to pyrite or other insoluble sulfides (Huerta and Morse, 1992). The variability in the amounts of soluble $\mathrm{V}$ registered can be explained by the complexation with organic compounds originated the nearby "chapopoteras" (Scholz et al., 2009). Vanadium is found in the environment primarily as $\mathrm{V}(\mathrm{V})$. Vanadium $(\mathrm{V})$ interacts with a variety of organic compounds including humic and fulvic acids, and minerals, most importantly with iron oxides (Van and Jawoski, 1980).

\section{Metal Distribution and Principal Component Analyses}

Core N1. The normalization of total metals data trends for $\mathrm{Cr}\left(\mathrm{Cr}_{\mathrm{T}}\right), \mathrm{Ni}\left(\mathrm{Ni}_{\mathrm{T}}\right)$ and $\mathrm{V}\left(\mathrm{V}_{\mathrm{T}}\right)$ in $\mathrm{N} 1$ did not show significant changes because anthropogenic activities provided the lack of variation with depth (Figure 2). On the other hand, normalized $\mathrm{Ba}_{\mathrm{T}}$ values present changes throughout the core perhaps due to the supplies of barite $\left(\mathrm{BaCO}_{3}\right.$; PEP-UNAM, 2008). Normalized $\mathrm{Fe}_{\mathrm{T}}$ and $\mathrm{Mn}_{\mathrm{T}}$ values show changes along the core. Variations in the concentration of these redox-active metals (Stumm and Morgan, 1996) is related to diagenetic processes, which are strongly dependent on the concentration of 


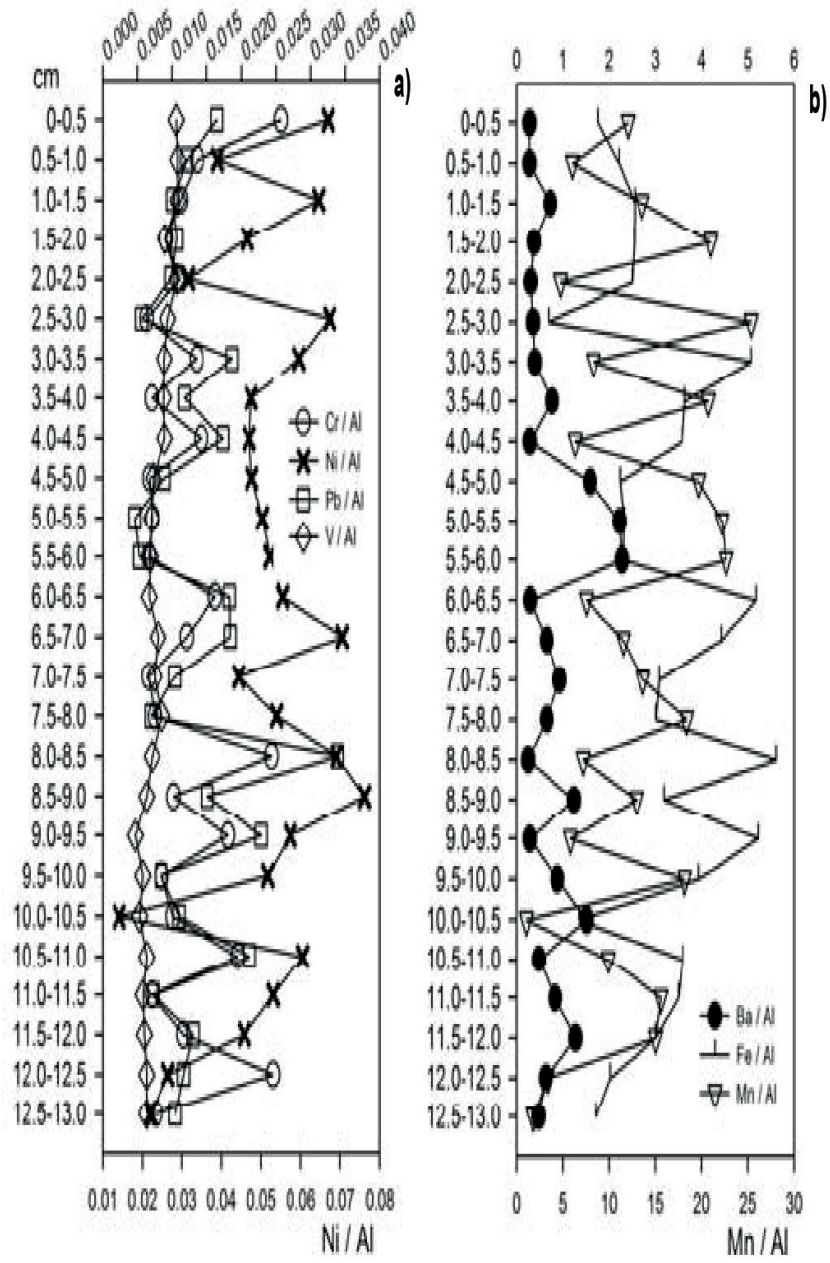

Figure 2. Normalized total metals to Al

dissolved $\mathrm{O}_{2}, \mathrm{pH}$, and $\mathrm{E}_{\mathrm{H}}$ values (Finney and Huh, 1989). At the same time, the high $\mathrm{Fe}_{\mathrm{T}}$ and $\mathrm{Mn}_{\mathrm{T}}$ values reported (Figure 2) in the core-upper layer(s) is consistent with inputs from the Coatzacoalcos River.

Normalized $\mathrm{Fe}_{\mathrm{T}}$ and $\mathrm{Mn}_{\mathrm{T}}$ values show changes along the core. Variations in the concentration of these redox-active metals (Stumm and Morgan, 1996) are related to diagenetic processes, which are strongly dependent on the concentration of dissolved $\mathrm{O}_{2}, \mathrm{pH}$, and $E_{H}$ values (Finney and Huh, 1989). At the same time, the high $\mathrm{Fe}_{\mathrm{T}}$ and $\mathrm{Mn}_{\mathrm{T}}$ values reported (Figure 2) in the coreupper layer(s) are consistent with inputs from the Coatzacoalcos River.

A significant statistical correlation $(p<0.05, n=26)$ (Table 1) between normalized total metals at $0-13 \mathrm{~cm}$ depth becomes evident. These results further confirm the idea of the existence of a significant supply of sus-
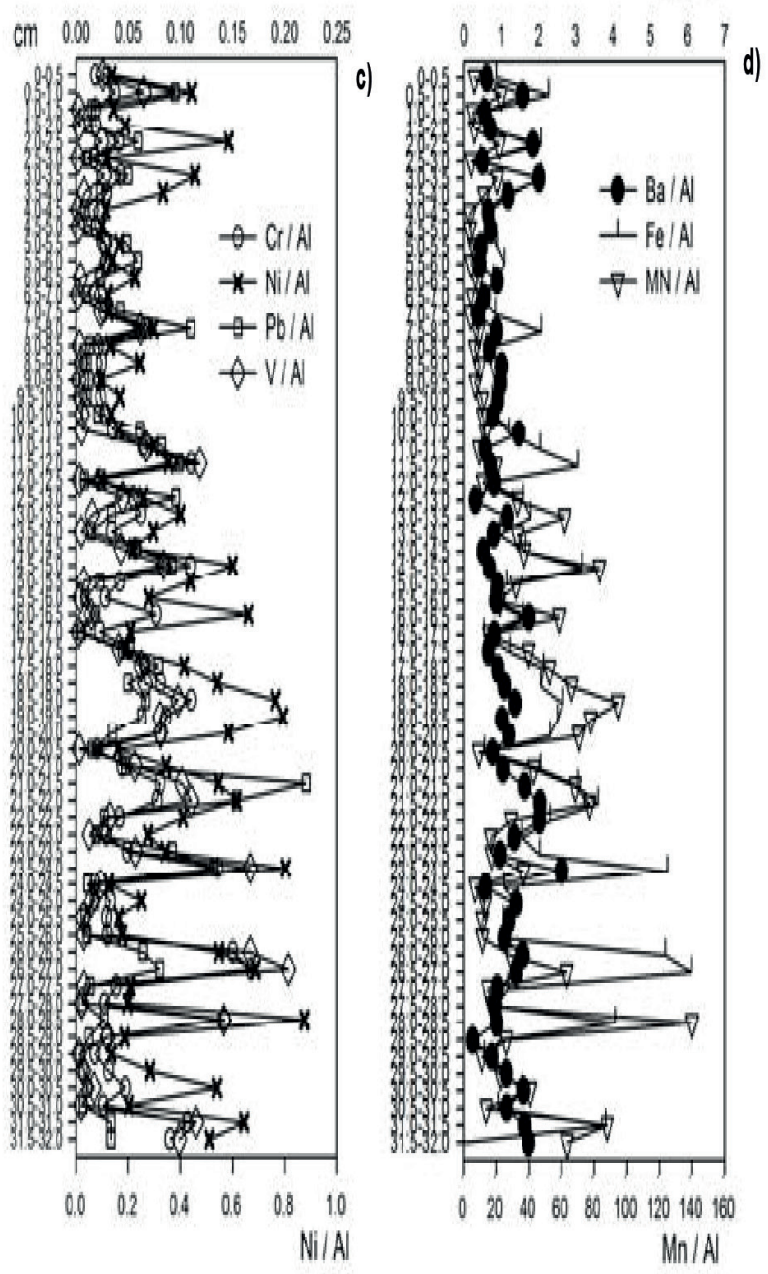

pended solids from the Coatzacoalcos River and/or atmospheric particles (PEP-UNAM, 2008; Vázquez et al., 2000). Cluster and Principal Components Analyses for total metals (S4, Supplementary Information Section) further suggest the prevalence of similar geochemical processes occurring at different core depths. Likely, a non-homogeneous distribution of organic matter of showed about microenvironments with varying "redox" potential values.

Our results for absorbed metals provide an indication that the accumulation of $\mathrm{Cr}\left(\mathrm{Cr}_{\mathrm{a}}\right)$ and $\mathrm{Ni}\left(\mathrm{Ni}_{\mathrm{a}}\right)$ is best explained by anthropogenic activities (Figure 3). With respect to $\mathrm{Ba}_{\mathrm{a}^{\prime}} \mathrm{Fe}_{\mathrm{a}^{\prime}} \mathrm{Mn}_{\mathrm{a}^{\prime}} \mathrm{Pb}_{\mathrm{a}}$ and $\mathrm{V}_{\mathrm{a}^{\prime}}$ visible changes are present along the core. Correlations with statistical significance $(p<0.05, n=64)$ (Table 1$)$, except for $\mathrm{Ba}$ $\left(\mathrm{Ba}_{\mathrm{a}}\right)$ become evident, in consistency with the anthropogenic activities from the petroleum industry. 

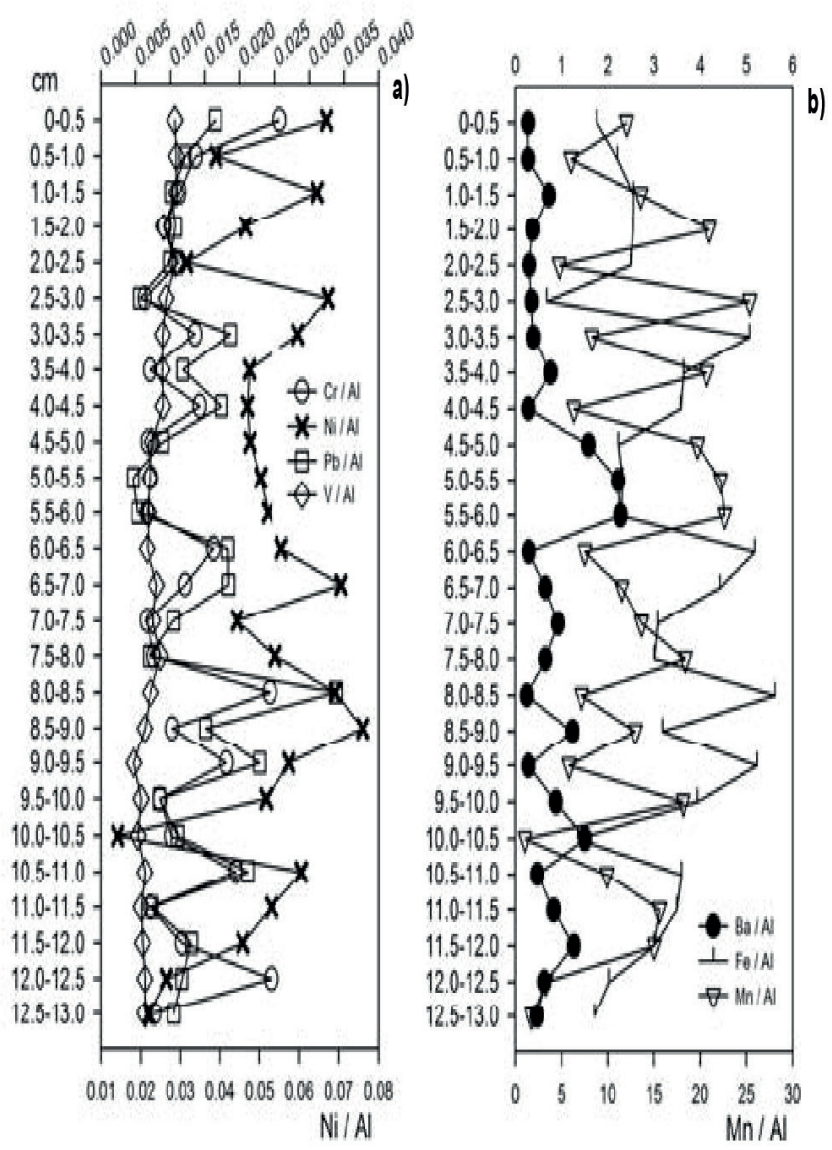
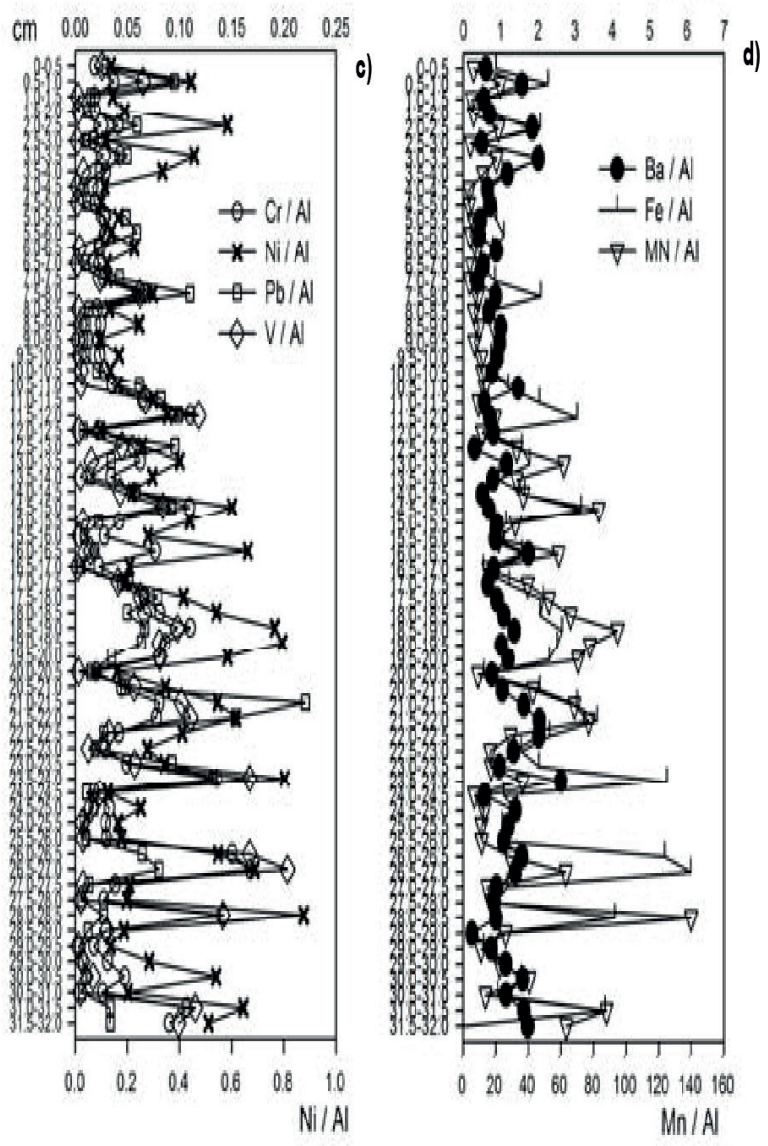

Figure 3. Normalized absorbed metals to Al

Core N2. Cluster and principal components analyses of normalized data for total metals in N2 are explained because prevailing similarities between geochemical processes with depth. Data conglomerates become evident (S4, Supplementary Information Section). Normalization on the accumulation of total metals show similar changes for all metals with depth (Figure 3) A high correlation of normalized-total metals, except for $\mathrm{Ba}_{\mathrm{T}}$ and $\mathrm{Mn}_{\mathrm{T}}(p<0.05, \mathrm{~N}=64)$ (Table 1) (PEP-UNAM, 2008) was observed.

Normalization of data trends for sorbed metals show significant changes along the core. Data variability becomes more notorious compared to N1. This is particularly true for the cases of $\mathrm{Ba}_{\mathrm{a}}$ and $\mathrm{Fe}_{\mathrm{a}^{\prime}}$ The close proximity of natural "chapopoteras" and high concentrations of oil derivatives is thought to influence the compartmentalization of metals.
Magnitude values for $\mathrm{Fe}_{a}$ serves as an indication of metal mobility with depth. By contrast, obtained values for $\mathrm{Cr}_{\mathrm{a}}$ and $\mathrm{Ni}_{\mathrm{a}}$ suggest variations to a lesser degree and, thereby, a lower mobility. Particularly so, for the case of $\mathrm{Ni}_{\mathrm{a}}$. Hence, natural "chapopoteras" have an effect on the environmental mobility and compartmentalization of $\mathrm{Cr}_{\mathrm{a}}$ and $\mathrm{Ni}_{\mathrm{a}}$. Variations in $\mathrm{V}_{\mathrm{a}}$ magnitude values determined along the core is in agreement with vanadium input originated from natural "chapopoteras", arguably in the form of either vanadium-porphyrin or vanadium-non-porphyrines complexes (Fish and Komelenic, 1984). The behavior of $\mathrm{Pb}_{\mathrm{a}}$ denotes little changes along the core, with accumulation in the deep zones only (Balsam et al., 2007).

Our results show a lack of correlation between normalized absorbed metals data trends $(p<0.05 ; n=64)$. However, data trends for $\mathrm{V}_{\mathrm{a}}$ show a significant correla- 
tion with data trends for $\mathrm{Cr}_{\mathrm{a}}$ and $\mathrm{Fe}_{\mathrm{a}^{\prime}}$ in consistency with the idea of supplies in the deep zone originated from the Grijalva River (Table 1; PEP-UNAM, 2008; Vázquez et al., 2000).

Core N3. Normalization of data trends for total metals show variations for the $\mathrm{Fe} / \mathrm{Al}$ and $\mathrm{Mn} / \mathrm{Al}$ ratios, in consistency with normalized data trends for N1. These findings can be explained in part because both zones receive water supply from the Grijalva River (Figure 1). Perhaps the decreases in magnitude values observed can be attributed to reactions between $\mathrm{Fe}$ and Mn with $\mathrm{HS}^{-}, \mathrm{S}^{=}$, and/or other metals (Stumm and Morgan, 1996).

The $\mathrm{Ba} / \mathrm{Al}$ ratio shows variations probably because the formation of Ba-carbonates (e.g., $\mathrm{BaCO}_{3}$ ) or sulfates $\left(\mathrm{BaSO}_{4}\right.$; Hurtgen et al., 1999). The $\mathrm{Cr} / \mathrm{Al}$ ratio presents similar variations, with no indication of the presence of $\mathrm{Cr}$ in the beaches of Tabasco (Vázquez et al., 2006;
Fuschsman et al., 2007). The Ni/Al and V/Al ratios present similar variations along the core and in agreement with those observed for $\mathrm{N} 1$. The $\mathrm{Pb} / \mathrm{Al}$ ratio in the top $(5$ to $6 \mathrm{~cm}$ ) show high values that may be a result of an unusual $\mathrm{Pb}$ supply originated from either the Grijalva River, the atmospheric supplies, or the oil-industry related activities (Varela, 2007). Furthermore, a correlation analyses of normalized data for total metals, namely $\mathrm{Fe} / \mathrm{Al}$ with $\mathrm{Mn} / \mathrm{Al}, \mathrm{Ni} / \mathrm{Al}$ with $\mathrm{V} / \mathrm{Al}$, and $\mathrm{Ni} / \mathrm{Al}$ with $\mathrm{V} / \mathrm{Al}$ were found to be statistically significant $(p<$ $0.05 ; n=24$; Table 1). These results further confirm an influence of sediments originated from oil wells. Additional cluster and principal components analyses for normalized data of total metals reveal four conglomerates formed by the $\mathrm{Fe} / \mathrm{Al}, \mathrm{Mn} / \mathrm{Al}, \mathrm{Ni} / \mathrm{Al}$ and $\mathrm{V} / \mathrm{Al}$ ratios, while those presenting no statistical significance were found to be the $\mathrm{Pb} / \mathrm{Al}$ and $\mathrm{Ba} / \mathrm{Al}$ ratios (Balsam et al., 2007), (S4, Supplementary Information Section).

Table 1. Multiple correlation for total and sorbed metals

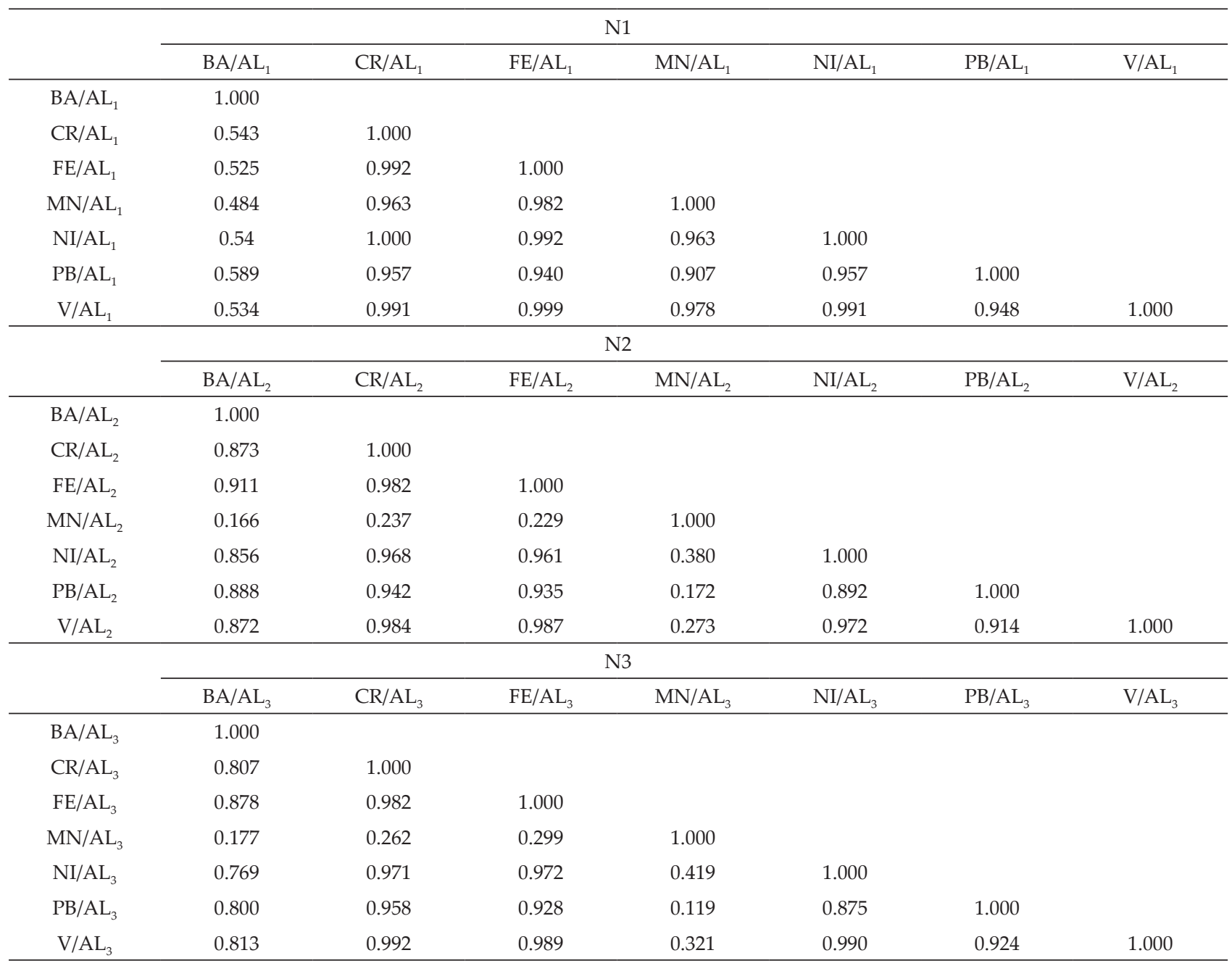


Cores N1, N2, and N3. Principal components analyses of total metals data sets for the three cores show three different groupings (S5, Supplementary Information Section). The core N3 shows a metal grouping, with the exception of $\mathrm{Pb} / \mathrm{Al}$ and $\mathrm{Ba} / \mathrm{Al}$. A second group of conglomerates in N2 is observed, with the exception of $\mathrm{Ba} /$ Al. A third metal conglomerate becomes evident for N1, with the exception of Mn/Al. The later results are explained in part by a higher input of Mn to N1 relative to $\mathrm{N} 2$ or N3 originated from heterogeneous-industrial activities at the Coatzacoalcos River vicinity (Vázquez et al., 2000; PEP-UNAM, 2008; Geissen et al., 2009).

Finally, normalized data trends obtained for N1 were found to be similar to those reported for the time series of stations near the influence of the Coatzacoalcos River (PEP-UNAM, 2008). Likewise, normalized data trends obtained for N2 were found to be similar to those reported for the time series for stations near the "chapopoteras" (PEP-UNAM, 2008). Normalized data trends obtained for N3 were found to be similar to those reported for the time series of stations near the Grijalva River (Vázquez and Virender, 2004; Vázquez et al., 2006).

\section{Metal enrichment factors in marine sediments}

Diverse methods have been proposed for evaluating the degree and enrichment of metals in marine sediments (Salomons and Förstner, 1984; Abrahim and Parker, 2008). The simplest method for estimating the level of pollution factor involves the normalization of concentration values to grain size (Rubio et al., 2000). The Enrichment Factor (EF) is calculated on the basis of the AIT (where AIT is total aluminum and AlL is lixiviate aluminum) values according to supplementary information (S6 Supplementary Information Section).

Calculated EF values are classified according to Table 2 (Kumar and Edward, 2009).

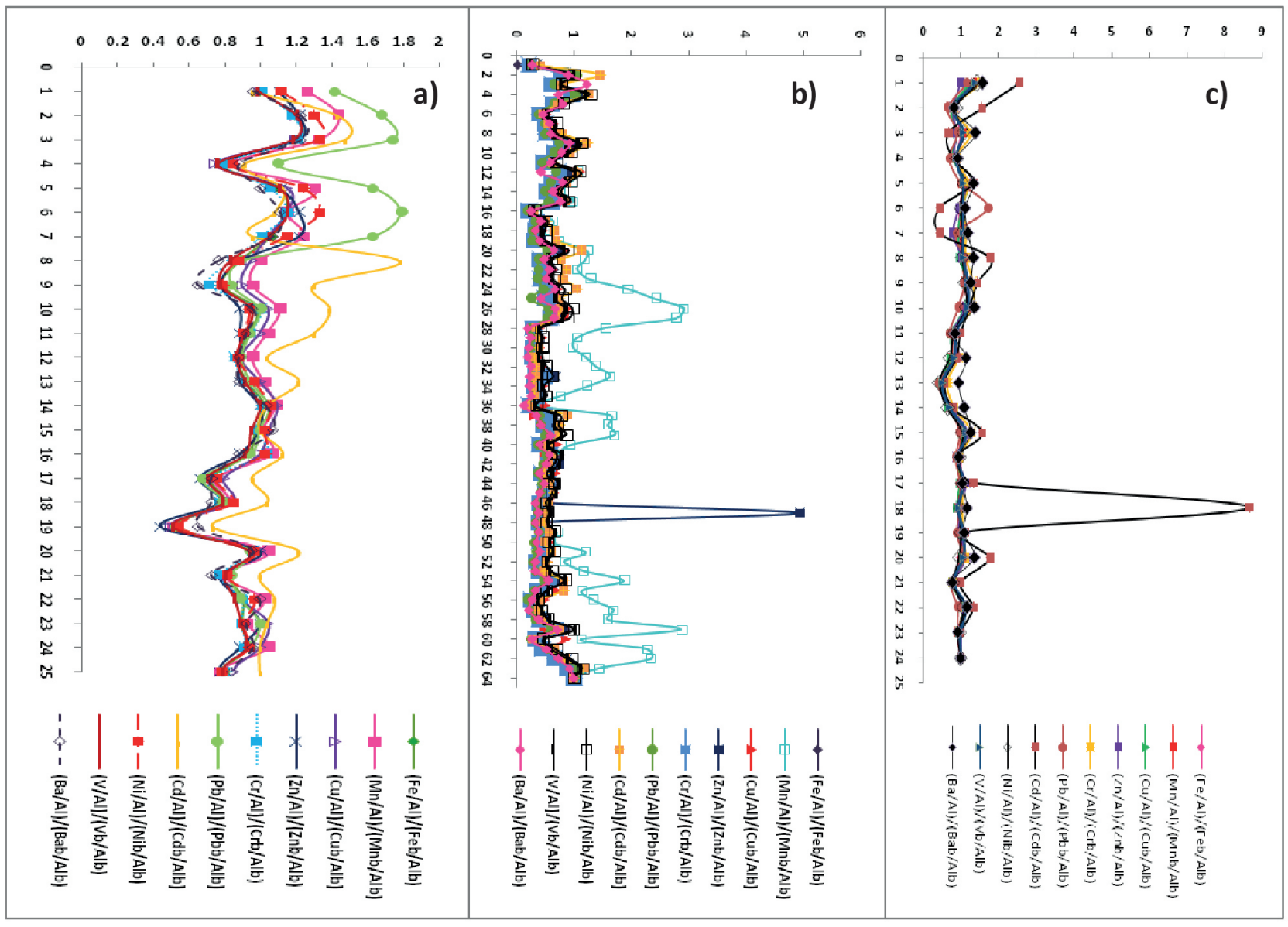

Figure 4. Enrichment factor values relative to the horizon of the cores 
Table 2. Classification of EF values according to Kumar and Edward (2009)

\begin{tabular}{cc}
\hline $\mathrm{EF}<2$ & Deficient to minimum enrichment \\
\hline $2 \leq \mathrm{FE} \leq 5$ & Moderate enrichment \\
$5<\mathrm{FE} \leq 20$ & Significant enrichment \\
$20<\mathrm{FE} \leq 40$ & High enrichment \\
$\mathrm{EF}>40$ & Extremely high enrichment \\
\hline
\end{tabular}

Our results for N1 (Figure 4) show that $\mathrm{Cr}$ and Ni present a minimum enrichment, $\mathrm{Fe}$ and $\mathrm{V}$ a moderate enrichment, and $\mathrm{Ba}, \mathrm{Mn}$ and $\mathrm{Pb}$ a significant enrichment. The significant enrichment of $\mathrm{Ba}, \mathrm{Mn}$ and $\mathrm{Pb}$ can be explained by industrial supplies and natural drainage received from the Coatzacoalcos River. Except for the case of $\mathrm{Ba}$, data trends for all metals show decreases in EF values with core depth (Figure 4).

Results for N2 at $c a .0 .5$ to 7.5, 18.0-27.0, and 30.0$32.0 \mathrm{~cm}$ depth indicate high EF values, except for the case of Mn (Figure 9). These results can be explained by the manganese oxides in organic matter mineralization or secondary environmental reactions (Luther et al., 1997; Hulth et al., 1999; Anschutz and Blanc, 1995; Anschutz et al., 2005).

Results for N3 show EF values corresponding to significant-to-high enrichment (Table 2; Figure 4). These results are all based on the proximity of the coast to the sampling site; therefore, EF values provide an indication of the influence from the Grijalva River on metal accumulation in sediments. Barium, $\mathrm{Fe}, \mathrm{Pb}, \mathrm{Ni}$, and $\mathrm{V}$ showed EF values that correspond to the category of significant enrichment, and manganese to the category of high enrichment.

These results may not be attributed to anthropogenic activities, but to the diagenetic processes instead. In contrast, chromium showed and EF value that correspond to the category of high enrichment. We explain these latter values due to the presence of chromite in the coasts of Tabasco (PEP-UNAM, 2008). The EF values determined in $\mathrm{N} 3$ for $\mathrm{Cr}$ were found to be high relative to those determined in N1 or N2 (Figure 4).

\section{Conclusions}

The metals were normalized with respect to $\mathrm{Al}$, which maintains a natural change in the south of the Gulf of Mexico. The analysis of conglomerate and principal components allowed us to compare metal the three sediment cores obtained from in close proximity to the Coatzacoalcos River, a natural "chapopoteras" and the Grijalva River. Analyses of EF values showed that me- tals present with the same core can present diverse enrichment behavior. Value for $\mathrm{EF}$ of $\mathrm{Mn}$ in N2 is consistent with a significant enrichment not attribute to anthropogenic activities (PEP-UNAM, 2008). Values EF for Mn accounts only import to Mn distribution. Either is necessary to distribute between $\mathrm{Mn}$ in geochemical processes and those introduced by the anthropogenic activity. In N3, EF values for $\mathrm{Cr}_{\mathrm{T}}$ were found to be high perhaps due to the precipitation-dissolution processes of chromite in the coast of Tabasco.

\section{Contents of the supplementary information section}

S1 Box plots of changes of total metals $(\mathrm{T})$ and absorbed (L).

S2(a) Change of the horizon of the depth of the total metals ( $\mathrm{Ba}$ and $\mathrm{Al}$ ).

S2(b) Change of the horizon of the depth of the total metals ( $\mathrm{Fe}$ and $\mathrm{Cr}$ ).

S2(c) Change of the horizon of the depth of the total metals ( $\mathrm{Ni}$ and $\mathrm{Mn}$ ).

S2(d) Change of the horizon of the depth of the total metals ( $\mathrm{V}$ and $\mathrm{Pb}$ ).

S3(a) (b) (c) (d) Change of the horizon of the depth of the metal absorbed.

S4(a) (b) (c) Cluster diagram and major components of the total metals in the sediment cores (N1, N2 and N3)

S5 Principal component analysis for the three cores.

S6 Formulae 1

S7 Location of sampling points in the southern Gulf of Mexico.

\section{References}

Abrahim G.M. and Parker R.J. Assessment of Heavy Metal Enrichment Factors and the Degree of Contamination in Marine Sediments from Tamaki Estuary, Auckland, New Zealand. Environ. Monit. Assess, volume 136 (issues 1-3), 2008: 227-38.

Anschutz T.P., Dedieu K., Desmazes F., Chaillou G. Speciation, Oxidation State and Reactivity of Particulate Manganese in Marine Sediments. Chem. Geol., volume 218, 2005: 265-279.

Anschutz P. and Blanc G. Chemical Mass Balances in Metalliferous Deposits from the Atlantis II Deep (Red Sea). Geochim. Cosmochim., Acta., volume 59, 1995: 4205-4218.

Balsam W., Damuth J.E., Deaton B. Marine Sediment Components: Identification and Dispersal Assessed by Diffuse Reflectance Spectrophotometry. International Journal of Environment and Health, volume 1 (issue 3), 2007: 403-426.

Balls P.W., Hull S., Miller B.S., Pirie J.M., Proctor W. Trace Metal in Scottish Estuarine and Coastal Sediments. Mar. Pollut. Bull., volume 34, 1997: 42-50. 
Bosecker K. Bioleaching: Metal Solubilization by Microorganisms. FEMS Microbiol. Rev., volume 20, 1997: 591-604.

Calmano W., Förstner U. Hong J. Mobilization and Scavenging of Heavy Metals Following Resuspension of Anoxic Sediments from the Elbe River, on: Environmental Geochemistry of Sulfide Oxidation, Charles N. Alpers, David W. Blowes (eds.). ACS Symposium Series, volume 550, Chapter 21, 1993, pp 298-321.

Carroll S., Peggy A., O’Day-Essera B., Randall S. Speciation and Fate of Trace Metals in Estuarine Sediments Under Reduced and Oxidized Conditions, Seaplane Lagoon, Alameda Naval Air Station (USA). Geochem. Trans., volume 3 (issue 10), 2002: 81-101.

Caschetto S. and Wollast R. Dissolved Aluminium in Interstitial Waters of Recent Marine Sediments. Geochim. Cosmochim. Acta., volume 43 (issue 3), 1979: 425-428.

Covelli S., Fontolan G. Application of a Normalization Procedure in Determining Regional Geochemical Baselines. Environ. Geol., volume 30, 1997: 34-45.

De Lorenz S.F.J. Dinámica de las partículas suspendidas en la zona Oriente de la Laguna de Términos, Camp., tesis (maestría en ingeniería ambiental), Facultad de Ingeniería, UNAM, 2004.

Finney B.P. and Huh C.A. History of Metal Pollution in the Southern California Bight: an Update. Environ. Sci. Technol., volume 23, 1989: 294-303.

Fish R.H. and Komlenic J.J. Molecular Characterization and Profile Identifications of Vanadyl Compounds in Heavy Petroleums by Liquid Chromatography / Graphite Furmace Atomic Absorption Spectrometry. Anal. Chem., volume 56, 1984: 510-517.

Ford T. and Ryan D. Toxic Metals in Aquatic Ecosystems: A Microbiological Perspective. Environ. Health Perspect., volume 103, 1995: 25-28.

Fuchsman M.L., Sorensen P., Magar M.V. and Wenning R.J. Chromium Geochemistry and Bioaccumulation in Sediments from the Lower Hackensack River, New Jersey. Arch. Environ. Contam. Toxicol., volume 53 (issue 3), 2007: 337-350.

Geissen V., Sánchez-Hernández R., Kampichler C., Ramos-Reyes R., Sepulveda-Lozada A., Ochoa-Goana S., de Jong B.H.J., Huerta-Lwanga E., Hernández-Daumas S. Effects of LandUse Change on Some Properties of Tropical Soils-An Example from Southeast Mexico. Geoderma, volume 151, 2009: 87-97.

Gutjahr M., Frank M., Stirling C.H., Klemm V., Van de Flierdt T., Halliday A.N. Reliable Extraction of a Deepwater Trace Metal Isotope Signal from Fe-Mn Oxyhydroxide Coatings of Marine Sediments. Chem. Geol., volume 242, 2007: 351-370.

Hakansson K., Karlsson S., Allard B. Effects of pH on the Accumulation and Redistribution of Metals in a Polluted Stream Bed Sediment. Sci. Total Environ., 1989: 87-88 and 43-57.

Huerta-Diaz M.A. and Morse J.W.. Pyritization of Trace Metals in Anoxic Marine Sediments. Geochim. Cosmochim. Acta., volume 56 (issue 7), 1992: 2681-2702.
Hulth S., Aller R.C., Gilbert F. Coupled Anoxic Nitrification/Manganese Reduction in Marine Sediments. Geochim. Cosmochim. Acta., volume 63, 1999: 49-66.

Hurtgen M.T., Lyons W.T., Ingall E.D., Calmano W., Ahlf W., Forstner U. Exchange of Heavy Metals Between Sediment Components and Water, on: Metal Speciation in the Environment, Broekaert J.A.C., Gucer S., Adams F. (Eds.), 1990, pp. 503-522.

Hurtgen, T.W. Timothy W. Lyons W.T., Ingall D.E., Cruse A.M. Anomalous Enrichments of Iron Monosulfide in Euxinic Marine Sediments and the Role of $\mathrm{H}_{2} \mathrm{~S}$ in Iron Sulfide Transformations: Examples from Efingham Inlet, Orca Basin, and the Black Sea. Am. J. Sci., volume 299, 1999: 556-588.

Jickells T.D. and Knap A.H. The Distribution and Geochemistry of Some Trace Metals in the Bermuda Coastal Environment. Estuarine Coastal Shelf Sci., volume 18, 1984: 245-262.

Kitano Y. and Fujiyoshi R. Partitioning of Cadmium, Copper, Manganese and Iron into Mineral and Organic Fractions in Core Sediments from the Osaka Bay, on: Kumar S.P. and Edward K.P., 2009. Indian J. of Mar. Sci., volume 38 (issue 2), 1980: 235-248.

Kumar S.P. and Edward K.P. Indian Journal of Marine Sciences, volume 38 (issue 2), 2009: 235-248.

Lan Y., Yang J., Deng B. Catalysis of Dissolved and Adsorbed Iron in Soil Suspension for Chromium (VI) Reduction by Sulfide. Pedosphere, volume 16 (issue 5), 2006: 572-578.

Luther III G.W., Sundby B., Lewis B.L., Brendel P.J., Silverberg N. Interactions of Manganese with the Nitrogene Cycle: Alternative Pathways to Dinitrogen. Geochim. Cosmochim., Acta 61, 1997, pp. 4043-4052.

Marcet-Miramontes P., Andrade-Couce M.L., Montero-Vilariño M.J. Contenido y enriquecimiento de metales pesados en sedimentos de la Ría de Vigo (España). Thalassas, volume 13, 1997: 87-97.

PEMEX-EXPLORACIÓN-PRODUCCIÓN-UNAM(PEP-UNAM). Campaña Oceanográfica SGM - 2008, Informe Final: Vázquez G.F. Seis, volume 3550, 2008.

Prospero J.M. Long-range Transport of Mineral Dust in the Global Atmosphere: Long-Range Transport of Mineral Dust in the Global Atmosphere. Impact of African Dust on the Environment of the Southeastern United States, volume 96 (issue 7), 1999: 3396-3403.

Prospero J.M., Olmez I., Ames M. Al and Fe in PM 2.5 and PM 10 Suspended Particles in South-Central Florida: The Impact of the Long Range Transport of African Mineral Dust. Water Air Soil Pollut., volume 125 (issue 1), 2004: 291-317.

Rubio B., Nombela M.A. y Vilas F. La contaminación por metales pesados en las Rías Baixas gallegas: nuevos valores de fondo para la Ría de Vigo (NO de España). J. Iberian Geol., volume 26, 2000: 121-149. 
Rubio B., Nombela M.A., Pazos O., Gago L., Vilas F. Distribution and Assessment of Heavy Metal Pollution in Surface Sediments in the Ria de Vigo (Galicia, NW Spain), on: Proc. 15 th International Sedimentological Congress, Alicante,1998, pp: 678-680.

Ryan J.D., Windom H.L. A Geochemical and Statistical Approach for Assessing Metal Pollution in Coastal Sediments, on: Metals in Coastal environments of Latin America, U. Seeliger (ed.), Springer-Verlag, Berlin, 1998, pp. 47-58.

Salomons W. and Förstner U. 1984. Metals in the hydrocycle. 349 p.

Schippers A. and Sand W. Bacterial Leaching of Metal Sulfides Proceeds by Two Indirect Mechanisms via Thiosulfate or via Polysulfides and Sulfur. Appl. Environ. Microbiol., volume 65 (issue1), 1999: 319-321.

Scholz-Böttcher B.M., Ahlf S., Vázquez-Gutiérrez F., Rullkötter J. Natural vs. Anthropogenic Sources of Hydrocarbons as Revealed Through Biomarker Analysis: A Case Study in the Southern Gulf of Mexico. Boletín de la Sociedad Geológica Mexicana, volume 61 (issue 1), 2009: 47-56.

Sparrevik M., Eek E., Grini R.S. The Importance of Sulphide Binding for Leaching of Heavy Metals from Contaminated Norwegian Marine Sediments Treated by Stabilization/Solidification. Environ. Technol., volume 30 (issue 8), 2009: 831-40.

Stumm W. and Morgan J.J. Aquatic Chemistry. An Introduction Emphasizing Chemical Equilibria in Natural Waters, 3a ed., Intersciene, US Wiley-Sons, 1996, 583 p.

Sutherland R.A. Bed Sediment-Associated Trace Metals in an Urban Stream, Oahu, Hawaii. Environ. Geol., volume 39, 2000: 611-637.

Tessier A., Campbell P.G.C., Bisson M. Sequential Extraction Procedure for the Speciation of Particulate Trace Metals. Anal. Chem., volume 51, 1979: 844-851.

Van-Zinderen-Bakker E.M. and Jaworski J.F. Effects of Vanadium in the Canadian Environment. National Research Council of Canada, Associate Committee on Scientific Criteria for Envi- ronmental Quality, Subcommittee on Heavy Metals and Certain Other Compounds, NRCC Issue 18132, 1980.

Varela V.E. Presencia de hidrocarburos y plaguicidas en Boca del Carmen, Laguna de Términos, Campeche, tesis (licenciatura en Ingeniero Químico), Facultad de Química, UNAM, enero 22, 2007.

Vázquez G.F., Rangel R., Mendoza Q.MA., Fernández J., Aguayo E., Palacio A., Virender K.S. Southern Gulf of Mexico, on: Seas at The Milennium an Enviromental Evaluation. Shepard C. (ed.), cap. 29, 2000, pp. 467-482.

Vázquez G.F. and Virender K.S. Major and Trace Elements in sediments of the Campeche Sound, southeast Gulf of Mexico. Mar. Pollut. Bull., volume 48, 2004: 87-90.

Vázquez G.F., Alexander V.H., Frausto C.A. Metales pesados (Cadmio, Cromo Níquel y Vanadio) absorbidos en sedimentos de la Sonda de Campeche. Campaña oceanográfica SGM9, on: XVI Congreso Nacional de Geoquímica, Mérida, Yucatán, 4 al 8 de septiembre, 2006.

Vázquez G.F. and Alexander V.H. Determinación de Lignina en sedimentos de la Sonda de Campeche Campaña OceanográficaSGM-2005, on:43CongresoMexicanodeQuímica,September 27- October 1o, 2008, Tijuana, Baja California.

Vela M.J.A. Evaluación de los Parámetros Bromatológicos en Sedimentos del Sur del Golfo de México 2001, tesis (licenciatura en Biología), Facultad de Ciencias, UNAM, October 2005.

Wiechuła D., Loska K., Korus I. Lead Partitioning in the Bottom Sediment of Rybnik Reservoir (Southern Poland). Water Air Soil Pollut., volume 164 (issues 1-4), 2000: 315-327.

Williams S.L. Aulenbach D.B., Clesceri N.C. Distribution of Trace Metals in Aquatic Environment, on: Rubin (ed.) Aqueous-Environmental Chemistry of Metals, Ann Arbor Science Publishers, Ann Arbor, Michigan, 1974, pp. 77-127.

Williamson R.B. and Wilcock R.J. The Distribution and Fate of Contaminants in Estuarine Sediments: Recommendations for Environmental Monitoring and Assessment, Technical Publication, 47, New Zealand, 1994. 


\section{Citation for this article:}

\section{Chicago citation style}

De Lorenz-Santos, Fernando Jesús, Felipe Vázquez, Georgina Fernández-Villagómez, Javiera Cervini-Silva. Cluster and Principal Components Analyses on the Contents of (Total and Sorbed) 2 Trace Metals in Fresh Marine Sediments from the South of the Gulf of Mexico. Ingeniería Investigación y Tecnología, XIV, 04 (2013): 511-522.

\section{ISO 690 citation style}

De Lorenz-Santos F.J., Vázquez F., Fernandez-Villagomez G., Cervini-Silva J. Cluster and Principal Components Analyses on the Contents of (Total and Sorbed) 2 Trace Metals in Fresh Marine Sediments from the South of the Gulf of Mexico. Ingeniería Investigación y Tecnología, volume XIV (issue 4), October-December 2013: 511-522

\section{About the authors}

Fernando Jesús De Lorenz-Santos. Holds a Master's in Engineering degree, is an expert on soil and aquifer pollution, water quality, sustainability, and environmental impact. He has more than 10 yrs of professional experience as a Professor at the Universidad Nacional Autonoma de Mexico (UNAM) and is appointed as a full-time professor (tenure) at the School of Engineering; has directed 10 B.Sc. theses and revised more than 30 theses. He is a Ph.D. candidate in the Earth Sciences Program at UNAM. His work has been presented and recognized in various national and international forums.

Georgina Fernández-Villagómez. She is an expert on storage, production, transportation, distribution, treatment and disposal of materials and hazardous wastes; prevention and mitigation of chemical hazards, and water quality control. She has more than 34 yrs of professional experience as a Professor at the Universidad Nacional Autonoma de Mexico (UNAM) and is appointed as a full-time professor (tenure) at the School of Engineering; has directed 34 B.Sc. theses, 37 master's theses, and 5 underway; has also held several professional positions at the National Center for Disaster Prevention. The work of Dr. Fernández has received worldwide recognition.

Javiera Cervini-Silva. Holds knowledge on environmental geochemistry, with more than 15 yrs of research experience, and is appointed as Titular Professor "C" (tenure) at Universidad Autonoma Metropolitana. She supervises thesis work at the Bachelor, Master, and Doctoral levels. Dr. Cervini has served on the editorial board of international journals. She is a member of the NASA Astrobiology Institute, Academia Mexicana de Ciencias, and SNI. She has been distinguished with the Perfil Deseable PROMEP recognition, and ad honorum positions at the Lawrence Berkeley National Laboratory (EUA) and the Laboratoire of Geophysique Interne et Technophysique-Observatoire des Sciences de la Terre de Grenoble (Francia). 